\title{
PENGARUH BAHAN BAKAR PREMIUM, PERTAMAX, PERTAMAX PLUS DAN VARIASI RASIO KOMPRESI TERHADAP KADAR EMISI GAS BUANG CO DAN HC PADA SUZUKI SHOGUN FL 125 SP TAHUN 2007
}

\author{
Eko Winarto, Husin Bugis dan C. Sudibyo \\ Prodi Pendidikan Teknik Mesin, Pendidikan Teknik dan Kejuruan, FKIP, UNS \\ Kampus UNS Pabelan Jl. Ahmad Yani 200, Surakarta, Tlp /Fax 0271718419
}

\begin{abstract}
The purpose of this research: (1) Investigated the motorcycle exhaust emissions Suzuki Shogun FL 125 SP in 2007 used premium,pertamax, and pertamax plus. (2) Investigated the motorcycle exhaust emissions Suzuki Shogun FL 125 SP in 2007 used variation of compression ratio. (3) Investigated the motorcycle exhaust emissions Suzuki Shogun FL 125 SP in 2007 used interaction premium,pertamax, pertamax plus, and variation of compression ratio.

This research was used experimental methods.The research was measurement at the Laboratory of Automotive Mechanical Engineering Education Program, JPTK, FKIP, UNS Surakarta to the address on Ahmad Yani road no. 200 Kartasura. Test of CO and HC exhaust gas emissions was used a gas analyzer type STARGAS 898. The population in this research was a motorcycle Suzuki Shogun FL 125 SP in 2007 and the sample in this research was a motorcycle Suzuki Shogun FL 125 SP in 2007 with engine number: F4A1ID113687.

Based on this researchcan be concluded: (1) The measurement premium fuel producedthe lowest emission in CO 3.884\% by 9.1:1 compression ratio and the the lowestexhaust gas emission levels in 168 ppmby 9.1:1 compression ratio. (2) The measurement pertamax fuel produced the lowest exhaust gas emission levels in CO $3.237 \%$ by 9.5:1 compression ratio and the the lowest exhaust gas emission levels in 210 ppm by 9.5:1 compression ratio(3) The measurement pertamax plus fuel produces the lowest exhaust gas emission levels in CO $2.615 \%$ by 10.2:1 compression ratio and the the lowest exhaust gas emission levels in 237 ppm by 9.5:1 compression ratio
\end{abstract}

Keywords: exhaust gas emissions of CO and HC, premium, pertamax, pertamax plus, compression ratio

\section{PENDAHULUAN}

Saat ini banyak penelitian untuk meminimalkan emisi gas buang.Meningkatnya isu tentang emisi gas buang terkait dengan semakin pedulinya masyarakat dunia atas perlindungan lingkungan. Udara telah mengalami pencemaran, yang antara lain berasal dari emisi gas buang yang dihasilkan berbagai sumber seperti pabrik dan kendaraan bermotor. Kendaraan bermotor sendiri telah lama menjadi salah satu sumber pencemar udara di banyak kota besar dunia. Gas-gas beracun dari jutaan knalpot setiap harinya menimbulkan masalah serius di banyak negara. Tidak terkecuali Indonesia, yang jutaan kendaraannya berbahan bakar bensin sehingga menjadi sumber pencemar udara terbesar di beberapa kota melebihi industri dan rumah tangga.

Menurut kementrian perindustrian pada tahun 2011 produksi sepeda motor mencapai 8,01 juta unit, 2012 produksi sepeda motor mencapai 7,1 juta unit dan tahun 2013 produksi sepeda motor ditargetkan 10 juta unit. Bertambahnya sepeda motor tiap tahunnya akan menambah jumlah emisi

JIPTEK, Vol. VI No.1, Januari 2013 gas buang pada kendaraan bermotor yang sudah menjadi penyumbang terbesar pencemaran udara.

Penggunaan kendaraan bermotor dapat menimbulkan dampak yang buruk bagi lingkungan, terutama emisi gas buang yang dihasilkan dari sisa pembakaran. Proses pembakaran bahan bakar dari motor bakar menghasilkan gas buang yang secara teoritis mengandung unsur $\mathrm{CO}, \mathrm{NO}_{2}, \mathrm{HC}, \mathrm{C}, \mathrm{CO}_{2}, \mathrm{H}_{2} \mathrm{O}$, dan $\mathrm{N}_{2}$ yang bersifat mencemari lingkungan dalam bentuk polusi udara.Unsur $\mathrm{CO}$ dan $\mathrm{HC}$ yang berpengaruh bagi kesehatan makhluk hidup perlu mendapatkan kajian khusus, karena unsur $\mathrm{CO}$ dan HC hasil pembakaran bersifat racun bagi darah manusia pada saat pernafasan sebagai akibat berkurangnya oksigen pada jaringan darah. Jika jumlah $\mathrm{CO}$ dan $\mathrm{HC}$ sudah mencapai jumlah tertentu atau jenuh di dalam tubuh maka akan menyebabkan kematian.

Besarnya emisi gas buang yang dihasilkan oleh kendaraan bermotor tidak boleh melebihi standar baku yang dikeluarkan oleh pemerintah, sesuai dengan Peraturan Menteri Negara Lingkungan Hidup 05 Tahun 2006 tentang ambang 
batas emisi gas buang kendaraan bermotor lama untuk sepeda motor produksi kurang dari tahun 2010 untuk dua langkah 4,5\% CO \& 1200 ppm $\mathrm{HC}$, untuk empat langkah 5,5\% CO \& 2400 ppm HC, sedangkan sepeda motor produksi lebih dari tahun 2010 baik dua langkah maupun empat langkah 4,5\% CO \& 2000 ppm HC.

Sepeda motor adalah motor bensin yang melakukan proses pembakaran dalam untuk menghasilkan tenaga dan mengeluarkan gas sisasisa pembakaran. Di mana gas sisa-sisa pembakaran yang dihasilkan adalah $\mathrm{CO}, \mathrm{NO}_{2}, \mathrm{HC}$, $\mathrm{C}, \mathrm{CO}_{2}, \mathrm{H}_{2} \mathrm{O}$, dan $\mathrm{N}_{2}$, hal ini dapat terjadi karena dipengaruhi oleh beberapa faktor.

Pertama kualitas bahan bakar, salah satunya angka oktan bahan bakar. Angka oktan merupakan bilangan yang menunjukkan ketahanan suatu bahan bakar terhadap knocking (detonasi). Semakin tinggi nilai oktan akan mengurangi kemungkinan terjadinya detonasi sebaliknya semakin rendah nilai oktan bahan bakar maka semakin memungkinkan terjadinya detonasi. Semakin kecilnya intensitas untuk berdetonasi maka campuran bahan bakar dan udara yang dikompresikan semakin banyak sehingga pembakaran yang terjadi lebih baik. Bahan bakar yang bernilai oktan tinggi sebaiknya digunakan pada mesin dengan kompresi tinggi begitu pula sebaliknya. Selain nilai oktan pada bahan bakar, zat aditif yang diberikan pada bahan bakar untuk memperbaiki kualitasnya juga mempengaruhi hasil pembakaran.

Kedua perbandingan bahan bakar dan udara atau air fuel ratio di mana perbandingan idealnya 14,8 : 1 yang jarang dicapai dan dipertahankan oleh mesin karena kualitas campuran bahan bakar dan udara selalu berubah pada berbagai tingkat putaran mesin dan pembebanan mesin. Perbandingan bahan bakar dan udara sangat berpengaruh terhadap proes pembakaran di mana perbandingan yang tidak ideal misalnya campurannya merupakan campuran kaya akan menyebabkan bahan bakar tidak terbakar habis karena kadar atau jumlah oksigen untuk membakar bahan bakar kurang sehingga dapat meningkatkan kadar karbon monoksida (CO) gas buang. Perbandingan campuran bahan bakar dan udara sudah dapat diatur ideal dengan tehnologi Electronic Fuel Injection (EFI).
Ketiga homogenitas campuran bahan bakar dan udara. Pembakaran yang sempurna dapat dicapai salah satunya dengan memperbaiki homogenitas campuran bahan bakar dan udara, karena homogenitas campuran bahan bakar dan udara yang rendah di mana ada partikel-partikel bahan bakar yang disebabkan karena proses pengkabutan bahan bakar tidak sempurna sehingga ada sebagian yang kaya bahan bakar dan sebagian lagi miskin bahan bakar. Adanya perbedaan komposisi campuran bahan bakar dan udara menyebabkan pembakaran yang terjadi tidak teratur yang menyebabkan tekanan yang ditimbulkan dalam silinder tidak sama sehingga terjadi detonasi. Selain itu ada sebagian bahan bakar yang terbakar tidak sempurna yang meningkatkan emisi gas buang pada kendaraan khususnya karbon monoksida (CO).

Keempat pusaran campuran bahan bakar dan udara baru yang masuk ke dalam ruang bakar. Arend dan Bernschot (1980) "pusaran di dalam ruang bakar menghasilkan pencampuran yang sempurna dari bahan bakar dan udara, sehingga pembakarannya terjadi sangat teratur, dengan akibat berkurangnya kemungkinan terbakar sendiri”.

Kelima kondisi ruang bakar juga berpengaruh pada proses pembakaran, adanya arang sisa-sisa pembakaran yang masih menyala di ruang bakar juga dapat menyebabkan campuran bahan bakar dan udara terbakar sendiri sebelum waktunya. Hal ini juga dapat menimbulkan terjadinya detonasi serta bahan bakar tidak terbakar sempurna (habis).

Keenam jenis dan kondisi busi, pemakaian jenis busi harus sesuai dengan ketentuan pabrik. Kebersihan elektroda busi dari kotoran maupun pelumas jika ada kebocoran kompresi, juga harus diperhatikan karena akan mempengaruhi percikan bunga api yang dihasilkan yang digunakan untuk proses pembakaran. Selain itu besar kecil penyetelan celah busi yang ideal adalah 0,6-0,7 $\mathrm{mm}$.

Ketujuh, memasang catalytic converter. Catalytic conventer merupakan komponen muffler dari emission control system, bertujuan untuk mengurangi $\mathrm{CO}, \mathrm{HC}$, dan $\mathrm{NOx}$ yang terkandung dalam gas bekas.

Untuk meningkatkan kesempurnaan pembakaran dapat dilakukan dengan cara-cara di 
atas, dalam penelitian ini akan di bahas tentang ruang bakar yang dimodifikasi sehingga merubah rasio kompresi dan disesuaikan dengan nilai oktan yang sudah ditetapkan pada bahan bakar premium dengan nilai oktan 88 , pertamax dengan nilai oktan 92, dan pertamax plus dengan nilai oktan 95 .

Rasio kompresi menunjukkan berapa jauh campuran udara dan bahan bakar yang dihisap selama langkah hisap dikompresikan dalam silinder selama langkah kompresi. Dengan kata lain adalah perbandingan dari silinder dan volume ruang bakar dengan piston pada posisi TMB $\left(\mathrm{V}_{2}\right)$ dengan volume ruang bakar dengan torak TMA $\left(\mathrm{V}_{1}\right)$. Rasio kompresi bisa dimodifikasi menjadi lebih rendah maupun lebih tinggi dengan dua cara yaitu merubah volume ruang bakar dan volume langkah piston. Penambahan volume ruang bakar akan mengakibatkan rasio kompresi menjadi lebih rendah, sebaliknya pengurangan ruang bakar mengakibatkan rasio kompresi menjadi lebih tinggi. Penambahan volume langkah piston akan mengakibatkan rasio kompresi menjadi lebih tinggi, sebaliknya pengurangan langkah piston mengakibatkan rasio kompresi menjadi lebih rendah.

Rasio kompresi dan nilai oktan bahan bakar mempunyai hubungan yang erat. Bahan bakar premium dengan nilai oktan 88 cocok untuk rasio kompresi 7-9:1, pertamax dengan nilai oktan 92 cocok untuk rasio kompresi 9-10:1, dan pertamax plus dengan nilai oktan 95 cocok untuk rasio kompresi 10-11:1.

Rasio kompresi dan nilai oktan bahan bakar berhubungan erat dengan emisi gas buang. Bahan bakar dengan oktan rendah sebaiknya menggunakan rasio kompresi yang rendah sedangkan bahan bakar dengan oktan tinggi sebaiknya menggunakan rasio kompresi yang lebih tinggi. Rasio kompresi yang sesuai dengan nilai oktan bahan bakar menghasilkan pembakaran yang sempurna, sehingga emisi yang dihasilkan juga menjadi lebih baik.

Shogun FL 125 SP tahun 2007 adalah jenis sepeda motor 4 tak, merupakan motor bensin silinder tunggal yang mempunyai diameter silinder $53,5 \mathrm{~cm}$, langkah piston $55,2 \mathrm{~cm}$ volume silinder $124,1 \mathrm{~cm}^{3}$ dan perbandingan kompresi 9,5:1. Dengan rasio kompresi 9,5:1 seharusnya bahan bakar yang dipakai adalah pertamax, tetapi masyarakat Indonesia pemilik Shogun FL 125 SP JIPTEK, Vol. VI No.1, Januari 2013 tahun 2007 tidak menyadari hal tersebut dan lebih memilih premium yang lebih murah.

\section{METODE PENELITIAN}

Rancangan atau desain penelitian digunakan untuk menunjukkan jenis penelitian, rancangan penelitian yang dipilih adalah yang paling memungkinkan peneliti untuk mengendalikan variabel-variabel lain yang diduga berpengaruh terhadap variabel terikat. Peneliti dalam penelitian ini menggunakan desain eksperimen.

Desain eksperimen adalah suatu rancangan percobaan (dengan tiap langkah tindakan yang betul-betul terdefinisikan) sedemikian sehingga informasi yang berhubungan atau diperlukan untuk. persoalan yang sedang diteliti dapat dikumpulkan (Sudjana, 1991: 1).

Eksperimen pada penelitian ini yaitu diawali dengan merubah rasio kompresi pada ruang mesin dari standart menjadi lebih rendah dan lebih tinggi. Perubahan rasio kompresi lebih rendah dilakukan dengan cara menambah gasket kepala silinder yang standarnya satu gasket menjadi dua dan tiga gasket. Perubahan rasio kompresi lebih tinggi dilakukan dengan mengurangi volume ruang bakar dengan cara pengurangan pada permukaan blok silinder 0,5 $\mathrm{mm}$. Variasi rasio kompresi yang dihasilkan adalah sebagai berikut:

Tabel 1. Desain Variasi Rasio Kompresi

\begin{tabular}{lll}
\hline KATEGORI & $\begin{array}{l}\text { RASIO } \\
\text { KOMPRESI }\end{array}$ & \multicolumn{1}{c}{ MODIFIKASI } \\
\hline Rendah & $8,7: 1$ & $\begin{array}{l}\text { Menambah volume ruang } \\
\text { bakar dengan menggunakan } \\
\text { tiga gasket kepala silinder }\end{array}$ \\
\hline Rendah & $9,1: 1$ & $\begin{array}{l}\text { Menambah volume ruang } \\
\text { bakar dengan menggunakan } \\
\text { dua gasket kepala silinder }\end{array}$ \\
\hline Standar & $9,5: 1$ & $\begin{array}{l}\text { Standar dari } \\
\text { pabrikan } \\
\text { gasket) } \quad \text { satu }\end{array}$ \\
\hline Tinggi & $10,2: 1$ & $\begin{array}{l}\text { Mengurangi volume ruang } \\
\text { bakar dengan mengurangi } \\
\text { permukaan blok silinder } \\
0,5 \mathrm{~mm}\end{array}$ \\
\hline
\end{tabular}

Masing-masing rasio kompresi diuji dengan bahan bakar premium dan pertamax, dan pertamax plus sehingga menghasilkan emisi gas buang $\mathrm{CO}$ dan $\mathrm{HC}$ pada setiap pengujian. 


\section{HASIL DAN PEMBAHASAN Deskripsi Data}

Berikut ini merupakan data hasil penelitian pengaruh bahan bakar premium, pertamax, dan pertamax plus dengan variasi rasio kompresi terhadap kadar emisi gas buang $\mathrm{CO}$ dan $\mathrm{HC}$ pada sepeda motor Suzuki Shogun FL 125 SP tahun 2007.

\section{Kadar Emisi Gas Buang CO pada Rasio Kompresi 8,7:1}

Tabel 2. Hasil Pengamatan Kadar Emisi Gas Buang CO pada sepeda motor Suzuki Shogun FL 125 SP dengan Rasio Kompresi 8,7:1 (\%)

\begin{tabular}{|c|c|c|c|c|}
\hline \multirow{2}{*}{$\begin{array}{l}\text { Sumber } \\
\text { Varian }\end{array}$} & & \multicolumn{2}{|c|}{ Bahan Bakar } & \multirow[b]{2}{*}{$\begin{array}{l}\text { Pert. } \\
\text { Plus }\end{array}$} \\
\hline & & Prem & Pertam & \\
\hline \multirow{2}{*}{$\begin{array}{l}\text { Rasio } \\
\text { Kompresi }\end{array}$} & $8,7: 1$ & $\begin{array}{l}4,881 \\
4,533\end{array}$ & $\begin{array}{l}4,993 \\
4,934\end{array}$ & $\begin{array}{l}5,475 \\
5,683\end{array}$ \\
\hline & & 4,817 & 5,395 & 5,594 \\
\hline Jumlah & & 14,231 & 15,322 & 16,752 \\
\hline Rata - rata & & 4,744 & 5,107 & 5,584 \\
\hline
\end{tabular}

Berdasarkan Tabel 2 hasil pengamatan kadar emisi gas buang $\mathrm{CO}$ pada penggunaan bahan bakar premium dengan rasio kompresi 8,7;1 diperoleh hasil kadar emisi gas buang $\mathrm{CO}$ rata-rata $4,744 \%$.

Berdasarkan Tabel 2 hasil pengamatan kadar emisi gas buang $\mathrm{CO}$ pada penggunaan bahan bakar pertamax dengan rasio kompresi 8,7;1 diperoleh hasil kadar emisi gas buang $\mathrm{CO}$ rata-rata $5,107 \%$.

Berdasarkan Tabel 2 hasil pengamatan kadar emisi gas buang $\mathrm{CO}$ pada penggunaan bahan bakar pertamax plus dengan rasio kompresi 8,7;1 diperoleh hasil kadar emisi gas buang $\mathrm{CO}$ rata-rata $5,584 \%$.

Berdasarkan Tabel 2 hasil pengamatan kadar emisi gas buang CO pada sepeda motor Suzuki Shogun FL 125 SP dengan rasio kompresi 8,7 : 1 diperoleh hasil kadar emisi gas buang CO terendah pada penggunaan bahan bakar premium dengan kadar emisi gas buang CO rata-rata $4,744 \%$

\section{Kadar Emisi Gas Buang CO pada Rasio Kompresi 9,1:1}

Tabel 3. Hasil Pengamatan Kadar Emisi Gas Buang CO pada sepeda motor Suzuki Shogun FL 125 SP dengan Rasio Kompresi9,1: 1(\%)

\begin{tabular}{|c|c|c|c|c|}
\hline \multirow{2}{*}{$\begin{array}{l}\text { Sumber } \\
\text { Varian }\end{array}$} & & \multicolumn{2}{|c|}{ Bahan Bakar } & \multirow[b]{2}{*}{ Pert. Plus } \\
\hline & & Prem & Pertam & \\
\hline \multirow{2}{*}{$\begin{array}{l}\text { Rasio } \\
\text { Kompresi }\end{array}$} & $9,1: 1$ & $\begin{array}{l}4,251 \\
3,760\end{array}$ & $\begin{array}{l}3,282 \\
3,628\end{array}$ & $\begin{array}{l}4,172 \\
4,132\end{array}$ \\
\hline & & 3,641 & 2,928 & 4,001 \\
\hline Jumlah & & 11,652 & 9,838 & 12,3055 \\
\hline Rata-rata & & 3,884 & 3,279 & 4,102 \\
\hline
\end{tabular}

Berdasarkan Tabel 3 hasil pengamatan kadar emisi gas buang $\mathrm{CO}$ pada penggunaan bahan bakar premium dengan rasio kompresi 9,1:1 diperoleh hasil kadar emisi gas buang $\mathrm{CO}$ rata-rata $3,884 \%$.

Berdasarkan Tabel 3 hasil pengamatan kadar emisi gas buang $\mathrm{CO}$ pada penggunaan bahan bakar pertamax dengan rasio kompresi 9,1:1 diperoleh hasil kadar emisi gas buang CO rata-rata $3,279 \%$.

Berdasarkan Tabel 3 hasil pengamatan kadar emisi gas buang $\mathrm{CO}$ pada penggunaan bahan bakar pertamax plus dengan rasio kompresi 9,1:1 diperoleh hasil kadar emisi gas buang $\mathrm{CO}$ rata-rata $4,102 \%$.

Berdasarkan Tabel 3 hasil pengamatan kadar emisi gas buang CO pada sepeda motor Suzuki Shogun FL 125 SP dengan rasio kompresi 9,1: 1 diperoleh hasil kadar emisi gas buang $\mathrm{CO}$ terendah pada penggunaan bahan bakar pertamax dengan kadar emisi gas buang $\mathrm{CO}$ rata-rata $3,279 \%$. 


\section{Kadar Emisi Gas Buang CO pada Rasio Kompresi 9,5:1}

Tabel 4. Hasil Pengamatan Kadar Emisi Gas Buang CO pada sepeda motor Suzuki Shogun FL 125 SPdenganRasioKompresi9,5:1(\%)

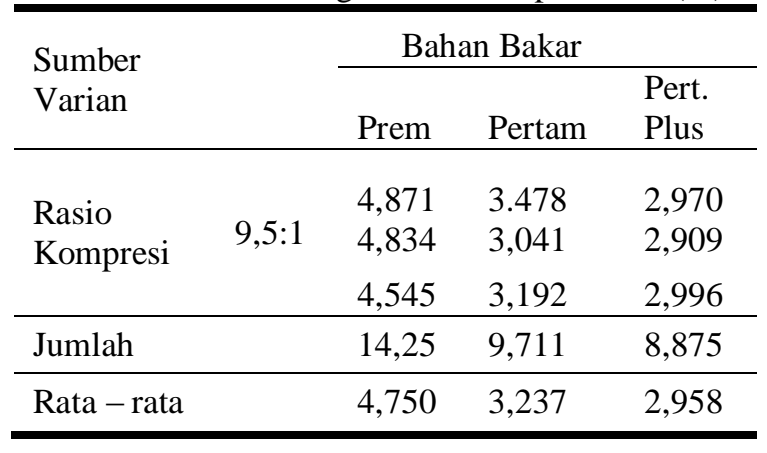

Berdasarkan Tabel 4 hasil pengamatan kadar emisi gas buang CO pada penggunaan bahan bakar premium dengan rasio kompresi 9,5:1 diperoleh hasil kadar emisi gas buang $\mathrm{CO}$ rata-rata $4,750 \%$.

Berdasarkan Tabel 4 hasil pengamatan kadar emisi gas buang $\mathrm{CO}$ pada penggunaan bahan bakar pertamax dengan rasio kompresi 9,5:1 diperoleh hasil kadar emisi gas buang $\mathrm{CO}$ rata-rata $3,237 \%$.

Berdasarkan Tabel 4 hasil pengamatan kadar emisi gas buang $\mathrm{CO}$ pada penggunaan bahan bakar pertamax plus dengan rasio kompresi 9,5:1 diperoleh hasil kadar emisi gas buang $\mathrm{CO}$ rata-rata $2,958 \%$.

Berdasarkan Tabel 4 hasil pengamatan kadar emisi gas buang CO pada sepeda motor Suzuki Shogun FL 125 SP dengan rasio kompresi 9,5: 1 diperoleh hasil kadar emisi gas buang $\mathrm{CO}$ terendah pada penggunaan bahan bakar pertamax plus dengan kadar emisi gas buang $\mathrm{CO}$ rata-rata $2,958 \%$.

\section{Kadar Emisi Gas Buang CO pada Rasio Kompresi 10,2:1}

Tabel 5. Hasil Pengamatan Kadar Emisi Gas Buang CO pada sepeda motor Suzuki Shogun FL 125 SP dengan Rasio Kompresi10,2:1(\%)

\begin{tabular}{|c|c|c|c|c|}
\hline \multirow{2}{*}{\multicolumn{2}{|c|}{$\begin{array}{l}\text { Sumber } \\
\text { Varian }\end{array}$}} & \multicolumn{3}{|c|}{ Bahan Bakar } \\
\hline & & Prem & Pertam & Pert. Plus \\
\hline \multirow{3}{*}{$\begin{array}{l}\text { Rasio } \\
\text { Kompresi }\end{array}$} & \multirow{3}{*}{ 10,2:1 } & 5,039 & 3,719 & 2,616 \\
\hline & & 4,959 & 3,648 & 2,712 \\
\hline & & 5,208 & 3,392 & 2,588 \\
\hline Jumlah & & 15,206 & 10,759 & 7,916 \\
\hline Rata - rata & & 5,069 & 3,586 & 2,639 \\
\hline
\end{tabular}

Berdasarkan Tabel 5 hasil pengamatan kadar emisi gas buang $\mathrm{CO}$ pada penggunaan bahan bakar premium dengan rasio kompresi 10,2:1 diperoleh hasil kadar emisi gas buang $\mathrm{CO}$ rata-rata $5,069 \%$.

Berdasarkan Tabel 5 hasil pengamatan kadar emisi gas buang $\mathrm{CO}$ pada penggunaan bahan bakar pertamax dengan rasio kompresi 10,2:1 diperoleh hasil kadar emisi gas buang $\mathrm{CO}$ rata-rata $3,586 \%$.

Berdasarkan Tabel 5 hasil pengamatan kadar emisi gas buang $\mathrm{CO}$ pada penggunaan bahan bakar pertamax plus dengan rasio kompresi 10,2:1 diperoleh hasil kadar emisi gas buang $\mathrm{CO}$ rata-rata $2,639 \%$.

Berdasarkan Tabel 5 hasil pengamatan kadar emisi gas buang CO pada sepeda motor Suzuki Shogun FL 125 SP dengan rasio kompresi 10,2:1 diperoleh hasil kadar emisi gas buang CO terendah pada penggunaan bahan bakar pertamax plus dengan kadar emisi gas buang $\mathrm{CO}$ rata-rata $2,639 \%$. 


\section{Kadar Emisi Gas Buang HC pada Rasio Kompresi 8,7:1}

Tabel 6. Hasil Pengamatan Kadar Emisi Gas Buang HC pada sepeda motor Suzuki Shogun FL 125 SP dengan Rasio Kompresi 8,7:1 (ppm)

\begin{tabular}{|c|c|c|c|c|}
\hline \multirow{2}{*}{$\begin{array}{l}\text { Sumber } \\
\text { Varian }\end{array}$} & & \multicolumn{3}{|c|}{ Bahan Bakar } \\
\hline & & Prem & Pertam & $\begin{array}{l}\text { Pert. } \\
\text { Plus }\end{array}$ \\
\hline \multirow{3}{*}{$\begin{array}{l}\text { Rasio } \\
\text { Kompresi }\end{array}$} & \multirow{3}{*}{$8,7: 1$} & 337 & 356 & 283 \\
\hline & & 331 & 378 & 312 \\
\hline & & 379 & 321 & 324 \\
\hline Jumlah & & 1047 & 1055 & 919 \\
\hline Rata - rata & & 349 & 352 & 306 \\
\hline
\end{tabular}

Berdasarkan Tabel 6. hasil pengamatan kadar emisi gas buang $\mathrm{HC}$ pada penggunaan bahan bakar premium dengan rasio kompresi 8,7:1 diperoleh hasil kadar emisi gas buang $\mathrm{HC}$ rata-rata 349 ppm.

Berdasarkan Tabel 6 hasil pengamatan kadar emisi gas buang $\mathrm{HC}$ pada penggunaan bahan bakar pertamax dengan rasio kompresi 8,7:1 diperoleh hasil kadar emisi gas buang $\mathrm{HC}$ rata-rata $352 \mathrm{ppm}$.

Berdasarkan Tabel 6 hasil pengamatan kadar emisi gas buang $\mathrm{HC}$ pada penggunaan bahan bakar pertamax plus dengan rasio kompresi 8,7:1 diperoleh hasil kadar emisi gas buang $\mathrm{HC}$ rata-rata 306ppm.

Berdasarkan Tabel 6 hasil pengamatan kadar emisi gas buang HC pada sepeda motor Suzuki Shogun FL 125 SP dengan rasio kompresi 8,7:1 diperoleh hasil kadar emisi gas buang $\mathrm{HC}$ terendah pada penggunaan bahan bakar pertamax plus dengan kadar emisi gas buang $\mathrm{HC}$ rata-rata $306 \mathrm{ppm}$.

\section{Kadar Emisi Gas Buang HCpada Rasio Kompresi 9,1:1}

Tabel 7. Hasil Pengamatan Kadar Emisi Gas Buang HC pada sepeda motor Suzuki Shogun FL 125 SP dengan Rasio Kompresi 9,1:1 (ppm)

\begin{tabular}{|c|c|c|c|c|}
\hline \multirow{2}{*}{$\begin{array}{l}\text { Sumber } \\
\text { Varian }\end{array}$} & & \multicolumn{3}{|c|}{ Bahan Bakar } \\
\hline & & Prem & Pertam & Pert. Plus \\
\hline \multirow{3}{*}{$\begin{array}{l}\text { Rasio } \\
\text { Kompresi }\end{array}$} & \multirow{3}{*}{$9,1: 1$} & 204 & 225 & 371 \\
\hline & & 161 & 293 & 315 \\
\hline & & 138 & 220 & 321 \\
\hline Jumlah & & 503 & 738 & 1007 \\
\hline Rata - rata & & 168 & 246 & 336 \\
\hline
\end{tabular}

Berdasarkan Tabel 7 hasil pengamatan kadar emisi gas buang HC pada penggunaan bahan bakar premium dengan rasio kompresi 9,1:1 diperoleh hasil kadar emisi gas buang $\mathrm{HC}$ rata-rata $168 \mathrm{ppm}$.

Berdasarkan Tabel 7 hasil pengamatan kadar emisi gas buang HC pada penggunaan bahan bakar pertamax dengan rasio kompresi 9,1:1 diperoleh hasil kadar emisi gas buang $\mathrm{HC}$ rata-rata 246 ppm.

Berdasarkan Tabel 7 hasil pengamatan kadar emisi gas buang HC pada penggunaan bahan bakar pertamax plus dengan rasio kompresi 9,1:1 diperoleh hasil kadar emisi gas buang $\mathrm{HC}$ rata-rata $336 \mathrm{ppm}$.

Berdasarkan Tabel 7 hasil pengamatan kadar emisi gas buang HC pada sepeda motor Suzuki Shogun FL 125 SP dengan rasio kompresi 9,1:1diperoleh hasil kadar emisi gas buang HC terendah pada penggunaan bahan bakar premium dengan kadar emisi gas buang HC rata-rata 168 ppm. 


\section{Kadar Emisi Gas Buang HCpada Rasio Kompresi 9,5:1}

Tabel 8. Hasil Pengamatan Kadar Emisi Gas Buang HC pada sepeda motor Suzuki Shogun FL 125 SP dengan Rasio Kompresi 9,5:1(ppm)

\begin{tabular}{|c|c|c|c|c|}
\hline \multirow{2}{*}{$\begin{array}{l}\text { Sumber } \\
\text { Varian }\end{array}$} & & \multicolumn{3}{|c|}{ Bahan Bakar } \\
\hline & & Prem & Pertam & Pert. Plus \\
\hline \multirow{3}{*}{$\begin{array}{l}\text { Rasio } \\
\text { Kompresi }\end{array}$} & \multirow{3}{*}{$9,5: 1$} & 470 & 154 & 247 \\
\hline & & 516 & 184 & 242 \\
\hline & & 512 & 292 & 222 \\
\hline Jumlah & & 1498 & 630 & 711 \\
\hline Rata - rata & & 499 & 210 & 237 \\
\hline
\end{tabular}

Berdasarkan Tabel 8 hasil pengamatan kadar emisi gas buang $\mathrm{HC}$ pada penggunaan bahan bakar premium dengan rasio kompresi 9,5:1 diperoleh hasil kadar emisi gas buang $\mathrm{HC}$ rata-rata 499 ppm.

Berdasarkan Tabel 8 hasil pengamatan kadar emisi gas buang $\mathrm{HC}$ pada penggunaan bahan bakar pertamax dengan rasio kompresi 9,5:1 diperoleh hasil kadar emisi gas buang $\mathrm{HC}$ rata-rata 210 ppm.

Berdasarkan Tabel 8 hasil pengamatan kadar emisi gas buang $\mathrm{HC}$ pada penggunaan bahan bakar pertamax plus dengan rasio kompresi 9,5:1 diperoleh hasil kadar emisi gas buang $\mathrm{HC}$ rata-rata 237 ppm.

Berdasarkan Tabel 8 hasil pengamatan kadar emisi gas buang HC pada sepeda motor Suzuki Shogun FL 125 SP dengan rasio kompresi 9,5:1 diperoleh hasil kadar emisi gas buang $\mathrm{HC}$ terendah pada penggunaan bahan bakar pertamax dengan kadar emisi gas buang HC rata-rata 210 ppm.

\section{Kadar Emisi Gas Buang HCpada Rasio Kompresi 10,2:1}

Tabel 9. Hasil Pengamatan Kadar Emisi Gas Buang HC pada sepeda motor Suzuki Shogun FL 125 SP dengan Rasio Kompresi 10,2:1 (ppm)

\begin{tabular}{|c|c|c|c|c|}
\hline \multirow{2}{*}{$\begin{array}{l}\text { Sumber } \\
\text { Varian }\end{array}$} & & \multicolumn{3}{|c|}{ Bahan Bakar } \\
\hline & & Prem & Pertam & Pert. Plus \\
\hline \multirow{3}{*}{$\begin{array}{l}\text { Rasio } \\
\text { Kompresi }\end{array}$} & \multirow{3}{*}{$10,2: 1$} & 512 & 265 & 228 \\
\hline & & 526 & 289 & 230 \\
\hline & & 546 & 322 & 266 \\
\hline Jumlah & & 1584 & 876 & 724 \\
\hline Rata - rata & & 528 & 292 & 241 \\
\hline
\end{tabular}

Berdasarkan Tabel 9 hasil pengamatan kadar emisi gas buang HC pada penggunaan bahan bakar premium dengan rasio kompresi 10,2:1 diperoleh hasil kadar emisi gas buang $\mathrm{HC}$ rata-rata $528 \mathrm{ppm}$.

Berdasarkan Tabel 9 hasil pengamatan kadar emisi gas buang HC pada penggunaan bahan bakar pertamax dengan rasio kompresi 10,2:1 diperoleh hasil kadar emisi gas buang $\mathrm{HC}$ rata-rata 292 ppm.

Berdasarkan Tabel 9 hasil pengamatan kadar emisi gas buang HC pada penggunaan bahan bakar pertamax plus dengan rasio kompresi 10,2:1 diperoleh hasil kadar emisi gas buang $\mathrm{HC}$ rata-rata $241 \mathrm{ppm}$.

Berdasarkan Tabel 9 hasil pengamatan kadar emisi gas buang HC pada sepeda motor Suzuki Shogun FL 125 SP dengan rasio kompresi 10,2:1 diperoleh hasil kadar emisi gas buang HC terendah pada penggunaan bahan bakar pertamax plus dengan kadar emisi gas buang $\mathrm{HC}$ rata-rata $241 \mathrm{ppm}$. 


\section{Pembahasan}

\section{Hasil Perhitungan Kadar Emisi gas Buang CO}

a. Rata - rata Kadar Emisi Gas Buang CO pada Penggunaan Bahan Bakar Premium

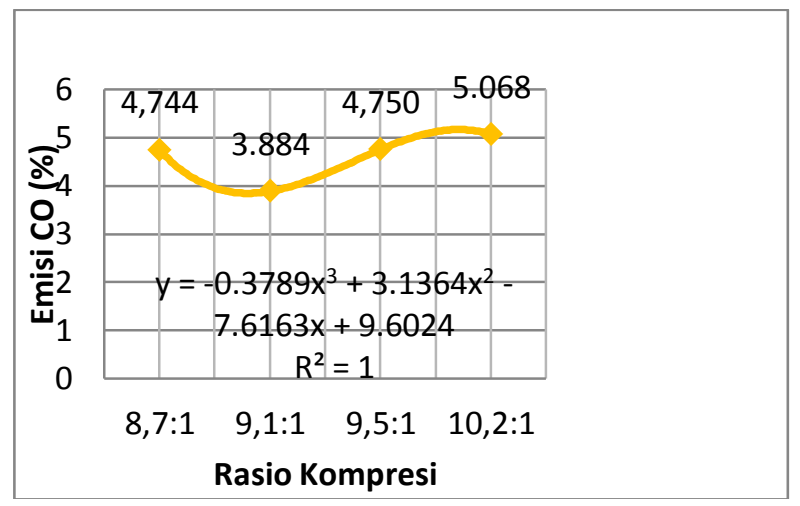

Gambar 1. GrafikPengamatan Kadar Emisi Gas Buang CO pada Penggunaan Bahan Bakar Premium dengan Rasio Kompresi 8,7 : 1; 9,1:1; 9,5:1; dan 10,2:1 (\%)

Berdasarkan Gambar 1 Grafik kadar emisi gas buang $\mathrm{CO}$ bahan bakar premium, kadar emisi gas buang CO pada rasio kompresi 8,7:1 sebesar $4,744 \%$, kadar emisi gas buang CO pada rasio kompresi 9,1:1 sebesar 3,884\%, mengalami penurunan kadar emisi sebesar 0,860\%, kadar emisi gas buang dengan pada rasio kompresi 9,5:1 sebesar $4,750 \%$, mengalami peningkatan kadar emisi CO sebesar 0,006\% kadar emisi gas buang pada rasio kompresi 10,2 sebesar 5,069\%, mengalami peningkatan kadar emisi sebesar $0,325 \%$ dari kadar emisi gas buang pada rasio kompresi 8,7:1. Penggunaan bahan bakar premium menghasilkan kadar emisi CO tertinggi pada rasio kompresi 10,2:1 hal ini dikarenakan premium mempunyai titik nyala rendah sehingga menimbulkan pree ignition yang mengakibatkan pembakaran tidak sempurna. Penggunaan bahan bakar premium menghasilkan kadar emisi $\mathrm{CO}$ terendah pada rasio kompresi 9,1:1 hal ini membuktikan bahwa bahan bakar premium memiliki pembakaran paling sempurna pada rasio kompresi 9,1:1. b. Rata - rata Kadar Emisi Gas Buang COpada Penggunaan Bahan Bakar Pertamax



Gambar 2. Grafik Pengamatan Emisi Gas Buang CO pada Penggunaan Bahan Bakar Pertamax dengan Rasio Kompresi 8,7 : 1; 9,1:1; 9,5:1; dan 10,2:1 (\%)

Berdasarkan Gambar 2 Grafik kadar emisi gas buang $\mathrm{CO}$ bahan bakar pertamax, kadar emisi gas buang $\mathrm{CO}$ pada rasio kompresi 8,7:1 sebesar $5,107 \%$, kadar emisi gas buang CO pada rasio kompresi 9,1:1 sebesar 3,279\%, mengalami penurunan kadar emisi sebesar 1,828\%, kadar emisi gas buang dengan pada rasio kompresi 9,5:1 sebesar 3,237\%, mengalami peningkatan kadar emisi CO sebesar 1,870\% kadar emisi gas buang pada rasio kompresi 10,2:1 sebesar 3,586\%, mengalami penurutan emisi sebesar $1,521 \%$ dari emisi gas buang pada rasio kompresi 8,7:1. Penggunaan bahan bakar pertamax menghasilkan kadar emisi CO tertinggi pada rasio kompresi 8,7:1 hal ini dikarenakan pertamax memiliki titik nyala yang tinggi dan tidak mudah terbakar pada rasio kompresi rendah sehingga pembakaran tidak sempurna. Penggunaan bahan bakar pertamax menghasilkan emisi $\mathrm{CO}$ terendah pada rasio kompresi 9,5:1 hal ini membuktikan bahwa bahan bakar pertamax memiliki pembakaran paling sempurna pada rasio kompresi 9,5:1. 


\section{c. Rata - rata Kadar Emisi Gas Buang COpada Penggunaan Bahan Bakar Pertamax Plus}



Gambar 3. GrafikPengamatan Kadar Emisi Gas Buang CO pada Penggunaan Bahan Bakar Pertamax Plus dengan Rasio Kompresi 8,7 : $1 ; 9,1: 1 ; 9,5: 1 ;$ dan 10,2:1 (\%)

Pada bahan bakar pertamax plus, kadar emisi gas buang $\mathrm{CO}$ pada rasio kompresi 8,7:1 sebesar 5,584\%, emisi gas buang $\mathrm{CO}$ pada rasio kompresi 9,1:1 sebesar 4,102\%, mengalami penurunan kadar emisi sebesar 1,482\%, kadar emisi gas buang dengan pada rasio kompresi 9,5:1 sebesar 2,958\%, mengalami peningkatan kadar emisi CO sebesar 2,626\% emisi gas buang pada rasio kompresi 10,2 sebesar 2,639\%, mengalami peningkatan kadaremisi sebesar 2,945\% dari kadar emisi gas buang pada rasio kompresi 8,7:1. Penggunaan bahan bakar pertamax plus menghasilkan kadar emisi CO tertinggi pada rasio kompresi 8,7:1 hal ini dikarenakan pertamax plus memiliki titik nyala yang tinggi dan tidak mudah terbakar pada rasio kompresi rendah sehingga pembakaran tidak sempurna. Penggunaan bahan bakar pertamax plus menghasilkan kadar emisi CO terendah pada rasio kompresi 10,2:1 hal ini membuktikan bahwa bahan bakar pertamax plus memiliki pembakaran paling sempurna pada rasio kompresi 10,2:1.

\section{Hasil Perhitungan Kadar Emisi Gas Buang} $\mathrm{HC}$

a. Rata - rata Kadar Emisi Gas Buang HCpadaPenggunaan Bahan Bakar Premium

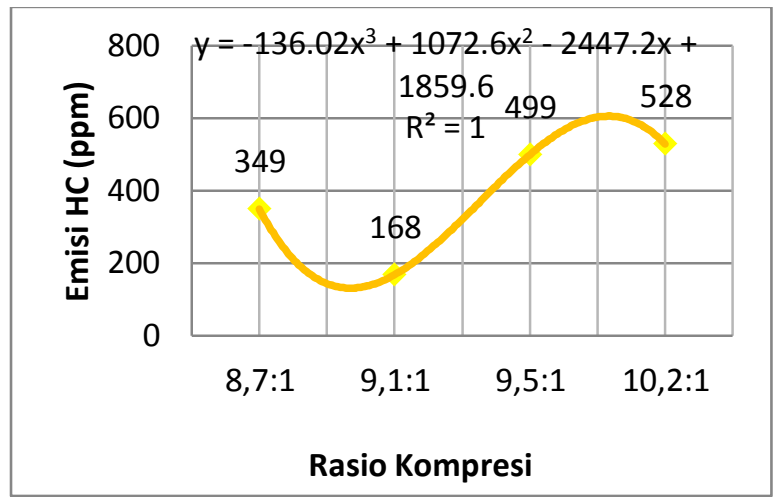

Gambar 4. Grafik Pengamatan Kadar Emisi Gas Buang HC pada Penggunaan Bahan Bakar Premium dengan Rasio Kompresi 8,7 : 1; 9,1:1; 9,5:1; dan 10,2:1 (ppm)

Pada bahan bakar premium, kadar emisi gas buang HC pada rasio kompresi 8,7:1 sebesar 349 ppm, kadar emisi gas buang HC pada rasio kompresi 9,1:1 sebesar 168 ppm, mengalami penurunan kadar emisi sebesar $181 \mathrm{ppm}$, kadar emisi gas buang dengan pada rasio kompresi 9,5:1 sebesar 499 ppm, mengalami peningkatan kadar emisi HC sebesar 150 ppm,kadar emisi gas buang pada rasio kompresi 10,2:1 sebesar 528 ppm, mengalami peningkatan kadar emisi sebesar 29 ppm.Penggunaan bahan bakar premium menghasilkan emisi $\mathrm{HC}$ tertinggi pada rasio kompresi 10,2:1 hal ini dikarenakan premium mempunyai titik nyala rendah sehingga menimbulkan pre ignition yang mengakibatkan pembakaran tidak sempurna. Penggunaan bahan bakar premium menghasilkan emisi $\mathrm{HC}$ terendah pada rasio kompresi 9,1:1 hal ini membuktikan bahwa bahan bakar premium memiliki pembakaran paling sempurna pada rasio kompresi 9,1:1. 


\section{b. Rata - rata Kadar Emisi Gas Buang HCpada Penggunaan Bahan Bakar Pertamax}

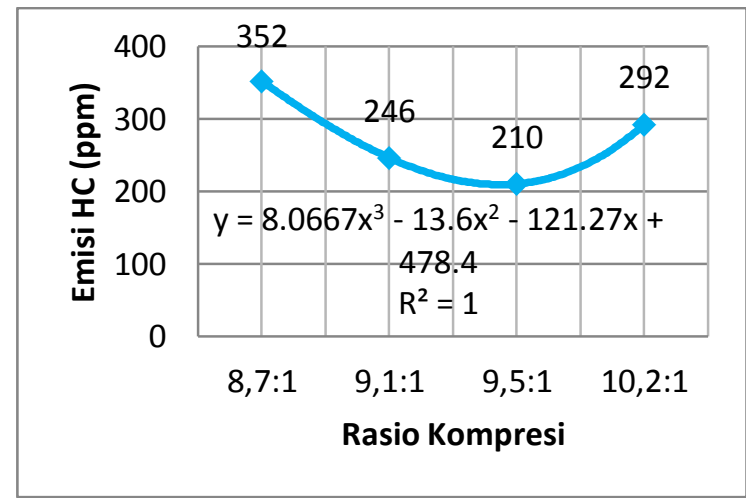

Gambar 5. GrafikPengamatan Kadar Emisi Gas Buang HC pada Penggunaan Bahan Bakar Pertamax dengan Rasio Kompresi 8,7 : 1; 9,1:1; 9,5:1; dan 10,2:1 (ppm)

Pada bahan bakar pertamax, kadar emisi gas buang HC pada rasio kompresi 8,7:1 sebesar $352 \mathrm{ppm}$, kadar emisi gas buang $\mathrm{HC}$ pada rasio kompresi 9,1:1 sebesar 246 ppm, mengalami penurunan kadar emisi sebesar 106 ppm, kadar emisi gas buang dengan pada rasio kompresi 9,5:1 sebesar 210 ppm, mengalami penurunan kadar emisi HC sebesar 142 ppm kadar emisi gas buang pada rasio kompresi 10,2:1 sebesar 292 ppm, mengalami penurutan kadar emisi sebesar 60 ppm. Penggunaan bahan bakar pertamax menghasilkan kadar emisi HC tertinggi pada rasio kompresi 8,7:1 hal ini dikarenakan pertamax mempunyai titik nyala rendah dan tidak mudah terbakar pada kompresi rendah sehingga mengakibatkan pembakaran tidak sempurna. Penggunaan bahan bakar pertamax menghasilkan emisi HC terendah pada rasio kompresi 9,5:1 hal ini membuktikan bahwa bahan bakar pertamax memiliki pembakaran paling sempurna pada rasio kompresi $9,5: 1$

\section{c. Rata - rata Kadar Emisi Gas Buang HCpada Penggunaan Bahan Bakar Pertamax Plus}

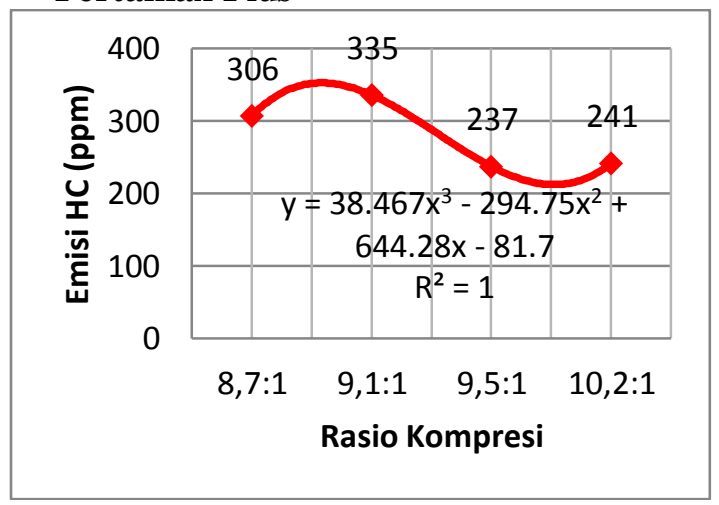

Gambar 6. Grafik Pengamatan Kadar Emisi Gas Buang HC pada Penggunaan Bahan Bakar Pertamax Plus dengan Rasio Kompresi 8,7 : $1 ; 9,1: 1 ; 9,5: 1$; dan 10,2:1 (ppm)

Pada bahan bakar pertamax plus, kadar emisi gas buang HC pada rasio kompresi 8,7:1 sebesar 306 ppm, kadar emisi gas buang HC pada rasio kompresi 9,1:1 sebesar 336 ppm, mengalami penurunan kadar emisi sebesar $30 \mathrm{ppm}$, kadar emisi gas buang dengan pada rasio kompresi 9,5:1 sebesar 237 ppm, mengalami peningkatan kadar emisi HC sebesar 69ppmkadar emisi gas buang pada rasio kompresi 10,2:1 sebesar 241 ppm, mengalami peningkatan kadar emisi sebesar 65 ppm. Penggunaan bahan bakar pertamax plus menghasilkan emisi HC tertinggi pada rasio kompresi 9,1:1 hal ini dikarenakan pertamax plus mempunyai titik nyala rendah dan tidak mudah terbakar pada kompresi rendah sehingga mengakibatkan pembakaran tidak sempurna. Penggunaan bahan bakar pertamax plus menghasilkan emisi $\mathrm{HC}$ terendah pada rasio kompresi 9,5:1 yang hanya berselisih 4 ppm dengan rasio kompresi 10,2:1 hal ini membuktikan pertamax plus pada 9,5:1 dan 10,2:1 sama - sama memiliki pembakaran yang sempurna.

\section{SIMPULAN}

Berdasarkan hasil penelitian yang sudah dilaksanakan dan telah diuraikan pada Bab IV dengan mengacu pada perumusan masalah, maka penelitian ini disimpulkan sebagai berikut:

1. Hasil pengukuran padasepeda motor Suzuki Shogun FL 125 SP tahun 2007 menggunakan bahanbakar premium menghasilkan kadar 
emisi gas buang $\mathrm{CO}$ terendah pada rasio kompresi $9,1: 1$ yaitu $3,884 \%$ dan menghasilkan kadar emisi gas buang $\mathrm{HC}$ terendah pada rasio kompresi 9,1:1 yaitu 168 ppm.

2. Hasil pengukuran pada sepeda motor Suzuki Shogun FL 125 SP tahun 2007 menggunakan bahan bakar pertamax menghasilkan kadar emisi gas buang $\mathrm{CO}$ terendah pada rasio kompresi 9,5:1 yaitu $3,237 \%$ dan menghasilkan kadar emisi gas buang $\mathrm{HC}$ terendah pada rasio kompresi 9,5:1 yaitu 210 ppm.

3. Hasil pengukuran pada sepeda motor Suzuki Shogun FL 125 SP tahun 2007 menggunakan bahan bakar pertamax plus menghasilkan kadar emisi gas buang $\mathrm{CO}$ terendah pada rasio kompresi 10,2:1 yaitu $2,639 \%$ dan menghasilkan kadar emisi gas buang HC terendah pada rasio kompresi 9,5:1 yaitu 237 ppm.

4. Pada rasio kompresi 8,7:1 menggunakan bahan bakar pertamax plus, mesin susah untuk dihidupkan dan putaran stasioner mesin tidak stabil bahkan mesin mati sebelum gas analyzer membaca emisi gas buang, maka diperlukan penyetelan karburator kembali.

Padarasio kompresi 10,2:1 menggunakan bahan bakar premium, saat sepeda motor diuji jalan jika mesin mengalami beban berat terjadi knocking atau ketukan, hal ini dikarenakan bahan bakar premium terbakar dulu sebelum waktunya.

\section{DAFTAR PUSTAKA}

Anonim. (1995). Toyota New Step 1 Training Manual. Jakarta: PT. Toyota AstraMotor

Arends, BPM dan Berenschot, H. Motor Bensin. Sukrisno, Umar. Jakarta: Erlangga

Arikunto, Suharsimi. (2009). Prosedur Penelitian Suatu Pendekatan Praktik. Jakarta: Rineka Cipta.

Arismunandar, W. (1988). Penggerak Mula Motor Bakar Torak. Bandung. ITB

BadanStandardisasiNasional.( 2013). Emisi gas buang - Sumber Bergerak - Bagian 3: Cara uji kendaraan bermotor kategori $\mathrm{L}$ pada kondisi idle. diperoleh $19 \quad$ Maret 2013 darihttp://sisni.bsn.go.id/index.php?/sni_ main/sni/detail_sni/7128

Daryanto. (2011). Prinsip Dasar Mesin Otomotif. Bandung: Alfabeta.

Daryanto. (2010). Teknik Konversi Energi. Bandung: Satu Nusa.

Daryanto. (2002). Teknik Otomotif. Jakarta: Bumi Aksara.

FardiazSrikandi. (1992). Polusi Air Dan Udara. Yogyakarta: Kanisius.

Hidayat, W. (2012). Motor Bensi Modern. Jakarta: Rineka Cipta.

Jama, J. (2008). Teknik Sepeda Motor Jilid 1 untuk SMK. Direktorat Pembinaan Sekolah Menengah Kejuruan, Jakarta: Direktorat Jenderal Manajemen Pendidikan Dasar dan Menengah, Departemen Pendidikan Nasional.

Kemenperin. (2013). Berita Industri Pasar Motor Pulih 2013. Diperoleh 01 September 2013, dari http://www.kemenperin.go.id/artikel/487 2/Pasar-Motor-Pulih-2013

K Kitagishi and I Yamane.(1981). Heavy Metal Pollution in Soils of Japan. Eds.KKitagishi and I Yamane. Tokyo.Japan Science SocietyPress.

Nortop, RS. (1995). Teknik Reparasi Sepeda Motor. Bandung: Pustaka Grafika.

Prastowo, A. (2011). Memahami Metode-Metode Penelitian. Jogjakarta: Ar-Ruzz Media.

Sastrawijaya, A.T. (2009). Pencemaran Lingkungan. Jakarta: Rineka Cipta

Sudjana. (1991). Desain dan Analisis Eksperimen. Bandung: Tarsito.

Sugiyono. (2009). Metode Penelitian Kuantitatif, Kualitatif dan $R \quad \& \quad D$. Bandung: Alfabeta.

Surakhmad, W. (1998). Pengantar Penelitian Ilmiah. Bandung: Tarsito.

SuyantoWardan (1989). Teori Motor Bensin. Jakarta: Kemendikbud

Wardhana, W.A. 1999. Dampak Pencemaran Lingkungan. Andi Offset. Yogyakarta.

Widodo, E. (2011). Otomotif Sepeda Motor. Bandung: Yrama Widya. 